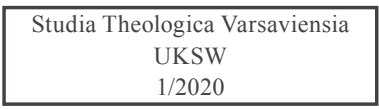

Anna WróblewsKa

\title{
IDEE W INTERPRETACJI DOGMATU
}

Teologia dogmatyczna to długa historia, pisana, jeśli spojrzeć na nią całościowo, od tysięcy lat, z inicjatywy Boga Objawiciela, ręką Kościoła, licznych teologów, filozofów, wielkich umysłów. Ze względu na jej bardzo złożoną strukturę wymaga delikatnego podejścia, uwzględniającego wielorakie kształtujące ją wpływy. Idei, jak można ją odczytywać i jak odbierać jej dogmaty, istnieje mnogość. W tym tekście przedstawiam kilka z nich oraz staram się ukazać ich wzajemne korespondowanie.

Interpretacja dogmatu jest procesem, którego właściwe rozumienie przysporzyć może wielu problemów tyleż teoretycznych, ileż praktycznych. Na tę rzeczywistość składają się różnorodne czynniki i biorą w niej udział rozmaite idee. Stąd też istnieje bardzo wiele definicji terminu dogmat w kontekście teologicznym. W większości są one zgodne co do swych zasadniczych części, ale różnią się nieco ujęciem tematu, spoglądając na niego z odmiennych perspektyw. Zamierzam przeanalizować kilka wybranych stanowisk odnośnie do interpretacji dogmatów i przedstawić ich punkt widzenia w tejże kwestii. Najpierw jednak podam, co rozumiem przez pojęcia dogmat oraz interpretacja.

Przez pojęcie interpretacja denotuję sposób rozumienia danego tekstu, zależny od perspektywy jej podmiotu oraz metody i narzędzi, jakimi się posługuje. Nie jest ona równoznaczna z rozumieniem jako takim, gdyż rozumienie jest właściwym uchwyceniem istoty rzeczy, zgodnym z intencjami autora i możliwościami odbiorcy. Interpretacja 


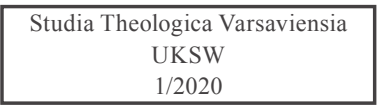

Anna WróblewsKa

\section{IDEAS IN INTERPRETATION OF DOGMA}

Dogmatic theology is a long story, written, in its entirety, for thousands of years, at the initiative of God the Revelator, with the hand of the Church, numerous theologians, philosophers and great intellectuals. Because of its very complex structure, it requires a careful approach, taking into account the many influences that shape it. There is a multitude of ideas on how to read it and how to perceive its dogmas. In this paper there are several of them, as the author attempts to show how they correspond with each other.

The interpretation of dogma is a process whose proper understanding can cause as many theoretical as practical problems. This reality comprises various factors and various ideas. Therefore, there are many definitions of the term dogma in the theological context. They mostly coincide in their essential parts, but they slightly differ in their approach to the subject, looking at it from different perspectives. The author intends to analyse a number of selected positions on the interpretation of dogma and present their viewpoint thereon. To begin with, however, the author presents the meaning of the terms dogma and interpretation.

By interpretation, the author denotes the way in which a given text is understood, depending on the perspective of its subject and the method and tools it uses. It is not equivalent to understanding as such, because understanding is a proper grasp of the essence of things, in accordance with the intentions of its author and the capabilities of the recipient. Interpretation is an attempt to understand and to grasp the 
stanowi próbę rozumienia, próbę uchwycenia tematu z danej perspektywy, którą stanowi przede wszystkim historia wspólnoty ${ }^{1}$, w której funkcjonuje podmiot. Interpretacja może być właściwa bądź błędna, rozumienie zaś jest poprawnym i możliwie najpełniejszym ogarnięciem treści. Patrząc w ten sposób na temat interpretacji Objawienia bądź dogmatów, stwierdzam, że w życiu doczesnym można głównie interpretować mowę Boga (zwłaszcza jeżeli chodzi o próbę przekazania Objawienia), z (pełnym) rozumieniem zaś ludzkość będzie miała do czynienia w czasach ostatecznych - będzie to najgłębsze jej dostępne uchwycenie Słowa. Absolutne rozumienie pozostanie zapewne zawsze poza zasięgiem stworzeń. Ponieważ obecnie dostępne są ludziom poznania cząstkowe (o czym wspomnę jeszcze poniżej) za rozumienie poznawanych treści odpowiada proces interpretacji.

Natomiast dogmat oznacza rzeczywistość rozwijającą się (nie w sensie relatywności jego znaczenia, ale naszego rozumienia jego treści - Duch Święty wciąż prowadzi Kościół do pełnego poznania prawdy [cf. J 16,13]), co oznacza, że jest historycznie zakorzeniony w konkretnym momencie. Stąd warto cofnąć się w niniejszej refleksji do początków użytkowania tego słowa w tekstach chrześcijańskich i judeochrześcijańskich oraz zauważyć, jaki sens posiada ono w kolejnych interpretacjach ${ }^{2}$.

Grecki tekst Starego Testamentu posługuje się słowem $\delta$ ó $\gamma \mu \alpha$ rzadko. Oznacza ono tam rozporządzenie, opinię, naukę. Podobnie jest w Nowym Testamencie, gdzie wyrażenie to ma znaczenie cesarskiego lub królewskiego nakazu albo też zarządzenia żydowskiego prawa. Co ciekawe, w kontekście chrześcijańskim obecne jest tylko raz, podczas relacji o tzw. Soborze Jerozolimskim (cf. Dz 15, 6-29), jednak jego rozporządzenie ma charakter czysto dyscyplinarny, nie posiada więc rangi późniejszych dogmatów ustanawianych przez sobory. Ojcowie Kościoła od początku IV wieku stosują grecki

${ }^{1}$ Międzynarodowa Komisja Teologiczna, Interpretacja dogmatów, [w:] J. Królikowski, Od wiary do teologii. Dokumenty Międzynarodowej Komisji Teologicznej 1969-1996, Kraków 2000, 273.

2 Cf. H. Wagner, Dogmatyka, Kraków 2007, 15. 
subject from a given perspective, which is primarily the history of the community ${ }^{1}$, in which the subject functions. Interpretation may be correct or incorrect, while understanding is the proper and fullest possible embrace of the content. Looking at the interpretation of Revelation or dogma in this way, the author concludes that in mortal life it is possible to interpret God's speech in the first place (especially when it comes to trying to convey Revelation), and that mankind will have to deal with (full) understanding in the final days - this will be the deepest grasp of the Word available to it. Absolute understanding will probably always remain beyond the reach of beings. As people are now able to access partial cognition (as the author discusses below), it is the process of interpretation that is responsible for understanding the content of the cognition.

Dogma, on the other hand, means a developing reality (not in terms of the relativity of its meaning, but of our understanding of its content - the Holy Spirit continues to lead the Church to a full knowledge of the truth [cf. Jn 16:13]), which means that it is historically rooted in a particular moment. Therefore, this reflection should take us back to the beginnings of the use of this word in Christian and Judeo-Christian texts, and see what sense it has in subsequent interpretations ${ }^{2}$.

The Greek text of the Old Testament uses the word $\delta$ ó $\gamma \mu \alpha$ rarely. There it means regulation, opinion, and science. It means regulation, opinion, and science. Likewise, in the New Testament it means an imperial or royal order or a decree of Jewish law. Interestingly, it is only present once in the Christian context, during the account of the so-called Jerusalem Council (cf. Acts 15: 6-29), but its regulation is purely disciplinary in nature, so it does not have the rank of later dogmas established by the councils. Since the beginning of the 4th century, the Fathers of the Church used the Greek term $\delta$ ó $\gamma \mu \alpha$, probably

${ }^{1}$ International Theological Commission, Interpretacja dogmatów, [in:] Królikowski, J. (2000) Od wiary do teologii. Dokumenty Międzynarodowej Komisji Teologicznej 1969-1996, Kraków, 273.

2 Cf. Wagner, H. (2007) Dogmatyka, Kraków, 15. 
termin $\delta$ ó $\gamma \mu \alpha$, czerpiąc zapewne z greckiego uzusu językowego, gdzie oznaczał on opinię o charakterze filozoficznym. Głównie jednak w tamtym stuleciu określa się tak herezję, natomiast pod koniec następuje wahanie - św. Hieronim (zm. ok. 420 r.) stosuje to słowo zarówno na określenie nauki błędnej, jak i wiary Kościoła. Dopiero u Ambrożego (zm. 397 r.) oznacza zasadniczo prawdziwą naukę. Natomiast jego uczeń, Augustyn (zm. 430 r.), używa go, opisując zarówno doktrynę chrześcijańską, jak i heretycką. Własne dogmaty posiadają też prawnicy, lekarze itp. Wyjątkowe znaczenie ma ten termin u Wincentego z Lerynu (zm. przed 450 r.). Z jego Commonitorium wnioskować można, że jest z reguły nauką katolicką, natomiast opinia heretycka jest określana jako dogma novum. Wielcy teolodzy jedenastowieczni (Piotr Damiani, Berengar, Piotr Czcigodny, a nawet Piotr Lombard) dogmatami nazywają i prawdy katolickie, i opinie heretyckie. Podobna dowolność występuje także u św. Tomasza z Akwinu (zm. 1274). W okresie średniowiecza chrześcijańskie prawdy wiary określane są zwykle nie jako dogmaty, ale articuli fidei. W okresie kontrreformacji dogmat to oficjalna nauka Kościoła, której należy bronić przed herezją protestantyzmu. Później, w celu odgraniczenia od racjonalizmu, Vaticanum I definiuje go jako prawdę objawioną, przez Kościół do wierzenia podaną (w sposób zwyczajny: w powszednim nauczaniu, kazaniach itd. albo nadzwyczajny tzn. poprzez uroczyste orzeczenia soborów i/lub papieży) ${ }^{3}$.

Z perspektywy pokrótce przytoczonej historii znaczenia tego słowa jasno wynika, że współczesna jego teologiczna interpretacja jest stosunkowo późna. Dogmat służy doktrynie, ujmując ją w przekazywalny system pojęciowy, korzystający z kategorii rozumienia i możliwości, jakie są w danym czasie do dyspozycji - pod względem językowym i rodzaju form myślowych ${ }^{4}$.

W ten sposób odbywa się nauczanie Ewangelii. Wręcz niezbędne jest poszukiwanie tego typu systemów pojęciowych dla językowego ujęcia wiary chrześcijańskiej, ponieważ niemożliwe jest uniknięcie

3 I Sobór Watykański, Dei Filius.

${ }^{4}$ H. Wagner, op. cit., 17. 
drawing on the Greek linguistic use, where it meant a philosophical opinion. But mainly in that century the term was used to refer to heresy, whereas at the end of the century some hesitation occurred St. Hieronymus (died in about 420) used the word both to describe erroneous teaching and the faith of the Church. Only Ambrose (died in 397) basically used the word for true science. However, his disciple, Augustine (died in 430), used it for describing both Christian and heretical doctrine. Lawyers, doctors etc. also have their own dogmas. This term is of exceptional importance for Vincent of Lerin (died before 450). From his Commonitory one can conclude that it is usually Catholic, while heretical opinion is referred to as dogma novum. Great eleventh-century theologians (Peter Damian, Berengar, Piotr Czcigodny and even Peter Lombard) call both Catholic truths and heretical opinions dogmas. A similar discretion is also found in St. Thomas of Aquinas (died in 1274). During the Middle Ages, Christian truths of faith were generally described not as dogmas, but as articuli fidei. At the time of the counter-reformation, dogma is the official teaching of the Church, which must be defended against Protestant heresy. Later, in order to distinguish it from rationality, Vaticanum I defines it as a revealed truth, given by the Church to believe in (in an ordinary way: in everyday teaching, sermons, etc., or extraordinary, i.e. by solemn decisions of councils and/or popes). ${ }^{3}$

As far as the brief history of the meaning of the word is concerned, it is clear that its contemporary theological interpretation is relatively late. The dogma serves the doctrine by incorporating it into a transferable conceptual system, using the categories of understanding and possibilities that are available at the time, in terms of the language and the type of thought forms ${ }^{4}$.

This is how the Gospel is taught. It is, in fact, necessary to search for conceptual systems of this kind for the linguistic presentation of the Christian faith, because it is impossible to avoid doctrinal disputes. It is therefore necessary to systematise Revelation (understood as the

${ }^{3}$ First Vatican Council, Dei Filius.

${ }^{4}$ Wagner, H. op. cit., 17. 
sporów na tle doktrynalnym. Stąd konieczna jest systematyzacja Objawienia (rozumianego jako suma twierdzeń, które Bóg zakomunikował o Sobie ${ }^{5}$. Punktami wytyczającymi te procesy są językowe formy wyrazu, które nazywamy dogmatami ${ }^{6}$. Aleksander Ganoczy nazywa dogmat Ewangelia w postaci doktrynalnej ${ }^{7}$. Jednak należy pamiętać, że ta postać doktrynalna od początku wyrasta z wymiaru doksologiczno-homologicznego, czyli przede wszystkim służą wyznaniu wiary ${ }^{8}$. Nie oznacza to jednak unieruchomienia wiary jako doktryny. Duch Święty prowadzi Kościół do całej prawdy, tak więc dogmat jest dopiero początkiem - jego sformułowanie oznacza podstawę do dalszych refleksji i pytań ${ }^{9}$ a także licznych interpretacji angażujących w tę rzeczywistość różnorakie idee, dzięki czemu nawiązywana jest także łączność między teologią a innymi naukami, czy nawet sztuką. Walter Kasper w napisanym przez siebie Katolickim katechizmie dla dorostych nazywa je otwartymi ku przyszłości $i^{10}$.

Pojęcie dogmatu jest stosunkowo młode w teologii, która w ostatnich latach przedkłada to jego rozumienie wielowątkowe ${ }^{11}$. Stąd też zagadnienie to stanowi problem hermeneutyczny, co szczególnie stara się zaznaczyć Grzegorz Strzelczyk w swoim tekście Dogmat jako granica: hermeneutyka Paula Beauchampa a interpretacja dogmatu(-ów) ${ }^{12}$. Postanowiłam przedstawić metodę G. Strzelczyka, gdyż wydaje mi się ona oryginalna i jednocześnie gruntownie przemyślana. Dokonuje on analizy sposobu interpretacji wspomnianego

5 Cf. K. Góźdź, Interpretacja dogmatów, „Studia Theologica Varsaviensia” (2018)1, 9.

${ }^{6}$ H. Wagner, op. cit., 17.

7 A. Ganoczy, Einführung in die Dogmatik, Darmstadt 1983, zwł. 13-16, cyt. za: H. Wagner, op. cit., 15-16.

${ }^{8}$ H. Wagner, op. cit., 17.

${ }^{9}$ G. Strzelczyk, Dogmat jako granica: hermeneutyka Paula Beauchampa a interpretacja dogmatu(-ów), [w:] Kościół wobec granic, red. J. Kempa, Katowice 2005, 9 .

${ }_{10}$ Walter Kasper, Katholisher Erwachsenen- Katechismus. Das Glaubensbekenntnis der Kirche, Bonn 1989, 57, cyt. za: H. Wagner, op. cit., 18.

11 G. Strzelczyk, op. cit., 1.

12 Ibidem. 
sum of the statements which God communicated about Himself ${ }^{5}$ ). The points that guide these processes are the linguistic forms of expression called dogmas ${ }^{6}$. Ganoczy refers to dogma as the Gospel in its doctrinal form ${ }^{7}$. It should be remembered, however, that from its very beginning this doctrinal form has been emerging from the doxological and homological dimension, that is to say, it primarily serves the confession of faith. ${ }^{8}$ However, this does not mean immobilising faith as a doctrine. The Holy Spirit leads the Church to the whole truth, so dogma is only the first step - when it is formulated it means the basis to further reflections and questions, ${ }^{9}$ However, this does not mean immobilising faith as a doctrine. The Holy Spirit leads the Church to the whole truth, so dogma is only the first step - when it is formulated it means the basis to further reflections and questions, as well as numerous interpretations involving various ideas in this reality, which also establishes a link between theology and other sciences or even art. Walter Kasper in his Catholic Catechism for Adults describes them as open to the future. ${ }^{10}$

The concept of dogma is relatively young in theology, which in recent years has put forward a multi-threaded understanding of $\mathrm{it}^{11}$. Therefore, this issue is a hermeneutical problem, which Grzegorz Strzelczyk particularly seeks to highlight in his study The Dogma as a borderline: Paul Beauchamp's hermeneutics and interpretation

5 Cf. Góźdź, K. Interpretacja dogmatów, „Studia Theologica Varsaviensia” (2018)1, 9 .

${ }^{6}$ Wagner, H. op. cit., 17.

7 Ganoczy, A. Einführung in die Dogmatik, Darmstadt 1983, cor.13-16, cited after: Wagner, H. op. cit., 15-16.

8 Wagner, H. op. cit., 17.

9 Strzelczyk, G. (2005) Dogmat jako granica: hermeneutyka Paula Beauchampa a interpretacja dogmatu(-ów), [in:] Kościót wobec granic, ed. Kempa, J. Katowice, 9.

${ }^{10}$ Kasper, Walter (1989) The Church's Confession of Faith: A Catholic Catechism for Adults (Communio Books) (English and German Edition), Bonn, 57, cited after: Wagner, H. op. cit., 18.

11 Strzelczyk, G. op. cit., 1. 
francuskiego teologa, P. Beauchampa, który ten proponuje stosować podczas lektury Starego Testamentu i przekłada ją na problem rozumienia dogmatów. Koncepcja owego jezuity opiera się na trzech zasadniczych punktach: arche, deuterozie i telosie ${ }^{13}$.

Pierwsze pojęcie oznacza chronologiczny, historyczny początek pism i towarzyszące okoliczności. Nie można go jednak stosować jako klucza interpretacyjnego, gdyż powoduje to rozwarstwianie się tekstu biblijnego na niespójne znaczenia.

Deuteroza nazywa Paul Beauchamp proces relektury, czyli ponownego odczytania i redakcji tekstu, docierając do jego najgłębszego sedna: Rozumieć, znaczy dotrzeć do podmiotu na grani tego, co wyraża, nie po to, by powtórzyć dosłownie to, co oznajmia, lecz by

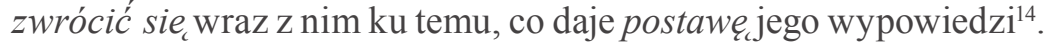
Rozumiana w ten sposób posiada też funkcję syntetyzującą - w świadomości czytelnika następuje połączenie poprzez proces zrozumienia różnych danych tradycji i powstawania myśli nowych i nienowych. Nienowe są to treści wcześniej już znane, zgodne z uprzednią logiką, nowe zaś, to te niebędące poprzednio na powierzchni pism ${ }^{15}$. P. Beauchamp tłumaczy deuterozę przez przykład analogii do dziecka uczącego się mówić - następuje powrót wypowiedzi ku samej sobie, identyczne sylaby nakładają się na siebie, stając się pierwszymi słowami.

Kolejny termin, telos, oznacza właściwą zasadę interpretacyjną jest tym, co działa w pismach, w którego kierunku zmierzają i wyznaczają go jako początek. Działa on bowiem podczas inicjacji procesu, ale nie powinien być mylony z arche. Telos jest źródłem, gdyż pismo od początku jest skierowane ku pełni sensu, która istnieje w przyszłości. Dokonać można następującego rozróżnienia: arche rodzi porządek diachronicznemu, natomiast telos jest zasadą synchroniczną. Jedno i drugie natomiast inicjuje pewną interpretację. Pierwsze jest perspektywą spojrzenia egzegezy historyczno-krytycznej, drugie

\footnotetext{
${ }^{13}$ Cf. Ibidem, 2-3.

${ }^{14}$ Ibidem, 3.

15 Ibidem.
} 
of $\operatorname{dogma}(s)^{12}$. The author of this paper decided to present the Strzelczyk's method, as it seems to be original and, at the same time, thoroughly considered. He analyses the interpretation of the aforementioned French theologian, Beauchamp, which he proposes to apply while reading the Old Testament and translates it into the problem of understanding dogmas. The concept of this Jesuit is based on three fundamental points: arche, deuterosis, and telos ${ }^{13}$.

The first term means a chronological, historical beginning of the writings and its circumstances. However, it cannot be applied as an interpretative key, as it causes a kind of stratification of the biblical text into inconsistent meanings.

Paul Beauchamp defines deuterosis as the process of re-referencing, i.e. rereading and editing a text, getting to its deepest point in order to understand means to reach out to the subject on the edge of what he or she expresses, not to repeat literally what he or she says, but to turn with him or her towards what gives him or her an attitude of expression ${ }^{14}$.

If understood in this way, it also has a synthesizing function - in the reader's consciousness there is a connection through the process of understanding of various traditions and creating new and non-new thoughts. Non-new ones are the contents previously known, consistent with the previous logic, while new ones are those not previously on the surface of the writings ${ }^{15}$. Beauchamp translates deuterosis with an analogy to a child learning to speak - the speech returns to itself, identical syllables overlap and become the first words.

The next term, telos, means the right principle of interpretation it is what works in the writings that they are heading towards and mark its beginning. It works at the initiation of the process, yet it should not be confused with arche. Telos is the source because from the very beginning the writing is directed towards the full sense that

\footnotetext{
${ }^{12}$ Ibidem.

${ }^{13}$ Cf. Ibidem, 2-3.

${ }^{14}$ Ibidem, 3.

15 Ibidem.
} 
zasadą hermeneutyki, choćby tej beauchampowskiej ${ }^{16}$. Podobną ideę, choć nie tożsamą, zawiera, nie używając jednak terminu telos, np. hermeneutyka orygenesowa, a także ogólnie aleksandryjskie metody interpretacji. Przez zastosowanie typologii, alegorii podczas procesu interpretacji ujawniają się powiązania semantyczne i symboliczne pomiędzy tekstami chronologicznie odległymi od siebie. Jest więc ona typem hermeneutyki synchronizującej. Jak słusznie zauważa B. Sesboüé, typologia jest obecna nie tylko wśród przedstawicieli szkoły aleksandryjskiej. Tę metodę stosowali już starotestamentalni prorocy, interpretując wydarzenia z historii Izraela jako zapowiedź przyszłych rzeczywistości mesjańskich i eschatologicznych ${ }^{17}$. Proponuję tutaj przyjrzeć się fragmentowi Listu do Galatów św. Pawła. Apostoł stosuje metodę interpretacji alegorycznej. Paweł odkrywa epizod o Hagar i Saraj jako figurę całej historii Izraela, ludu Bożego, a więc historii zbawienia. Proponowane przez niego zestawienie łączy dwa wydarzenia (narodziny Izmaela i narodziny Izaaka), dwa teksty Księgę Rodzaju oraz deutero-Izajasza (finalnie zaś trzy, włączając jego własny list), za pomocą jednego klucza: żywej zbawczej historii, z której oba biorą początek.

Ukazuje to przede wszystkim komplementarność mowy Bożej, jaką jest Pismo Święte. Historia święta opowiada się sama, może tak się dziać, gdyż jest rzeczywistością żywą (cf. Hbr 4, 12), czyli zawsze aktualną. Człowiek natomiast, odbierający Słowo jest istotą tymczasowo egzystującą na ziemi, musi więc dostosowywać się: doskonalić, aktualizować swoje spojrzenie na objawienie Tego, który jest Aktem.

Swój gatunek telos posiada w apokaliptyce, stanowiąc w ten sposób koniec i cel procesu. Dzięki temu ruch ponawianego odczytywania nie jest nieokreślony, ale posiada swoją metę. Tak więc stanowi on przyczynę celową, klucz interpretacyjny i ostateczny cel pism (choć, rzecz jasna, nie stanowi on klucza, za pomocą którego odczytać można wszystko).

\footnotetext{
16 Ibidem, 4.

17 B. Sesboüé, Bóg zbawienia. Tradycja, reguła i Symbole wiary. Ekonomia zbawienia. Rozwój dogmatów trynitarnych i chrystologicznych, Kraków 1999, 128.
} 
exists in the future. The following distinction can be made: arche gives birth to a diachronic order, whereas telos is a synchronous principle. Both initiates a certain interpretation. The first is the perspective of the historical-critical exegesis, the latter is the principle of hermeneutics, for instance, of Beauchamp ${ }^{16}$. A similar idea, yet not identical, is contained in e.g. Origen hermeneutics, as well as generally Alexandria's interpretation methods, yet without the term telos. By using typology, allegories during the process of interpretation, semantic and symbolic links between texts chronologically distant from each other are revealed. It is therefore a type of synchronising hermeneutics. As Sesboüé notes, typology is present not only among representatives of the Alexandria school, but it had already been used by the Old Testament prophets, interpreting the events in Israel's history as a foreshadowing of future messianic and eschatological realities. ${ }^{17}$ The author suggests that we look at a fragment of the Letter of St Paul to the Galatians. The Apostle uses the method of allegorical interpretation. St. Paul discovers the episode of Hagar and Sarai as a figure of the whole history of Israel, God's people, and therefore of salvation. What he proposes is a combination of two events (the birth of Ishmael and the birth of Isaac), two texts, the Book of Genesis and deutero-Isaiah (three, including his own letter), using one key: the living salvific history from which both originate.

This shows above all the complementarity of God's speech, namely the Bible. The holy story is told by itself, it may be so because it is a living reality (cf. Hebrews 4:12), which means it is always relevant. Man, on the other hand, who receives the Word, is a creature who temporarily exists on earth, so he must adapt: improve and update his view of the revelation of Him who is the Act.

It has its own kind of telos in the apocalyptic, thus constituting the end and goal of the process. Thanks to this, the movement of

16 Ibidem, 4.

17 Sesboüé, B. (1999) Sesboüé, B. (1999) God of Salvation. Tradition, Principle and Symbols of Faith. The Economics of Salvation. Development of Trinitarian and Christological Dogmas, Kraków, 128. 
Tę metodę stosuje G. Strzelczyk, przekładając ją na problem interpretacji dogmatu.

$\mathrm{Za}$ P. Beauchampem kontestuje arche jako główny klucz interpretacyjny (w tym wypadku: dogmatu). Choć studia nad kontekstem historycznym przyniosły wiele dobrego w rozumieniu prawd wiary, stosowanie ich jako fundamentalnej zasady grozi niebezpieczeństwem analogicznym do diachronizacji w egzegezie. Może to bowiem powodować rozkład dogmatów na ich składowe, a rozłączenie tradycji teologicznych, które je wygenerowały, prowadzi do utraty całości szerzej rozumianej rzeczywistości. Tak więc potrzebna jest alternatywa dla arche - G. Strzelczyk proponuje taką zasadą uczynić telos, dookreśla go jednak, w przeciwieństwie do P. Beauchampa, zmieniając nieco jego znaczenie. Francuski jezuita widział spełnienie telosu $\mathrm{w}$ apokaliptyce. Jednak sprawcą jego dynamiki nie jest eschatologia, ale Ten, który wszystko ku sobie pociaga ${ }^{18}$. Tu G. Strzelczyk przywołuje klarujące tę sytuację rozróżnienie św. Tomasza z Akwinu. Otóż rzeczywisty przedmiot naszej wiary (res) ostatecznie jest jeden: Bóg. W życiu doczesnym nigdy nie osiągamy jego pełnego (na nasze możliwości) poznania w jednorazowym oglądzie, ale na sposób właściwy dla człowieka - poprzez wielokrotne poznania cząstkowe ${ }^{19}$. Przenosząc tę konstatację na płaszczyznę dogmatyczną - poznaniom tym odpowiadają konkretne prawdy. Nie są one jednak w stanie wyczerpać prawdy o Bogu, dlatego wiara człowieka musi sięgać poza wszelkie sformułowania, ku res. Przyciąga ono do siebie, wytwarzając ów dynamizm, powodujący ponawianie interpretacji konkretnych danych tej Tajemnicy, nie pozwalając jednocześnie zamknąc się $\mathrm{w}$ żadnym ujęciu aspektowym ${ }^{20}$. Tak więc idea telosu okazuje się być po części zgodna z Tomaszowym res. Jest to transcendentna

18 G. Strzelczyk, op. cit., 6.

19 Ibidem, 7.

20 Jest to przykład tzw. koła hermeneutycznego. Zjawisko to polega na spiralnej strukturze procesu rozumienia, jako pytań i odpowiedzi, które umożliwiają angaż w tekst. Drugim aspektem tego koła niemożność zrozumienia całości, bez zrozumienia wszystkich jej części; nie da się również pojąć pojedynczych części, nie wiedząc jak działają one w ogólnej kompozycji, którą tworzą. 
rereading is not indefinite, but it has its finish. Thus, it is the cause, the interpretation key and the ultimate goal of the writings (although, of course, it is not the key to read everything).

This method is used by Strzelczyk, who translates it into a problem of interpretation of dogma.

Following Beauchamp, he contests the arche as the main interpretative key (in this case: dogma). Although studies of the historical context have brought about much positive in the understanding of the truths of the faith, applying them as a fundamental principle risks being dangerously similar to diachronism in exegesis. This may result in the decomposition of dogmas into their components, and the separation of theological traditions which generated them, leading to the loss of the entire broadly understood concept of reality. So there is a need for an alternative to arche - Strzelczyk proposes to make telos such a principle, but, unlike Beauchamp, he adds to it by changing its meaning a little. The French Jesuit saw the fulfilment of the telos in the apocalyptic. However, the perpetrator of its dynamics is not eschatology, but the One who attracts everything ${ }^{18}$. Here, Strzelczyk recalls the clear-cut distinction by St Thomas of Aquinas. For the real object of our faith (res) is ultimately one, i.e. God. In the worldly life, we never reach the full (as to our abilities) knowledge of it in a single viewing, but in a way that is appropriate for man - through multiple partial cognitions ${ }^{19}$. By transferring this statement to a dogmatic level, these cognitions correspond to certain truths. They are not, however, able to exhaust the truth about God, which is why human faith must go beyond all expressions, towards res that attracts to itself, creating this dynamism, which causes the reinterpretation of the particular data of this Mystery, while at the same time not allowing itself to be closed in terms of any aspect. ${ }^{20}$ So the idea of the telos turns out to be partly

18 Strzelczyk, G. op. cit., 6.

19 Ibidem, 7.

20 This is an example of the so-called hermeneutic circle. This phenomenon consists in the spiral structure of the process of understanding, as questions and answers, which allow for involvement in the text. The second aspect of the circle 
przyczyna celowa, synchronizująca w konkretną całość cząstkowe poznania. Tak więc u źródeł rozwoju tradycji dogmatycznej znajduje się sam Bóg. Tym, co odróżnia go od telosu P. Beauchampa jest powiązanie wiary istniejące między podmiotem a przedmiotem poznania. Relacja ta realizuje się w sposób poprawny we wspólnocie Kościoła, gdzie następuje właściwa tradycja i pogłębianie poznania. Jest to również miejsce, gdzie doświadczenie jednostki może zostać porównane z poznaniem wspólnoty. Skutki poznania jednostki mogą czynić pełniejszym poznanie wspólnoty, jeżeli są zgodne z jej dziedzictwem. Konieczny do takowego rozeznania jest tzw. sktadnik regulujący. Rodzi on to, co nazywamy dziś dogmatami. W szerokim tego słowa znaczeniu, pojawiły się, wg G. Strzelczyka, w momencie, kiedy pierwotna wspólnota chrześcijan uzmysłowiła sobie własną wyjątkowość i odrębność - od tej chwili doświadczenia jednostki mogły być uznane za będące częścią tej samej wiary, bądź wręcz przeciwnie. Dogmaty w ścisłym tego słowa znaczeniu są wyjątkowymi przejawami tych czynności, które ustanowione zostają, kiedy występuje jakaś zagrażająca wierze wspólnoty interpretacja. P. Beauchamp nie konkretyzuje wykonawcy aktu ustanowienia, w przypadku dogmatu sytuacja jest prostsza - podmiotem tej czynności jest kolegium Apostołów pod przewodnictwem św. Piotra i ich następcy. Tu swoje zastosowanie znajduje pojęcie deuterozy - powstaje wtedy nowa wypowiedź, poprzez odczytanie wcześniejszej tradycji w odmiennym kontekście. Taką relekturą jest każda wypowiedź dogmatyczna. W ten sposób przedstawione są wielkie sobory: nicejski - jako załącznik do Nowego Testamentu, chalcedoński-jako uzupełnienie nicejskiego. Z perspektywy chronologicznej są to odrębne teksty, które dzieli ponad wiek, ale z punktu widzenia koncepcji deuterozy są to kolejne doprecyzowania, które były konieczne z powodu powstawania nowych herezji. Każde z orzeczeń chrystologicznych jest więc kolejnym aktem relektury, z których żadne nie wyczerpuje sensu Tajemnicy ${ }^{21}$.

\footnotetext{
${ }^{21}$ G. Strzelczyk, op. cit., 8.
} 
consistent with St. Thomas's res. It is a transcendent intentional cause, synchronising partial cognition into a specific entity. Thus, at the source of the development of the dogmatic tradition is God Himself. What distinguishes him from Beauchamp's telos is the connection of faith existing between the subject and the object of cognition. This relationship is correctly implemented in the community of the Church, where the proper tradition and deepening of cognition takes place. It is also a place where the experience of the individual can be compared with the knowledge of the community. The effects of an individual's cognition can make a more complete knowledge of the community if they are compatible with its heritage. The so-called regulating ingredient is necessary for such discernment. It generates what we call dogmas today. According to Strzelczyk, they appeared, in the broad sense, when the original Christian community became aware of its own uniqueness and distinctiveness, and since then the experiences of individuals could be considered to be part of the same faith, or quite the contrary. Dogmas in the strict sense of the word are exceptional manifestations of those actions which are established when there is an interpretation of the community which threatens the faith. Beauchamp does not specify the executor of the act of establishment; in the case of dogma, the situation is simpler as the subject of the act is the College of Apostles under the leadership of St Peter and their successors. The concept of deuterosis comes into play here - a new statement is then made, by reading the earlier tradition in a different context. Such a kind of perception is every dogmatic utterance. The great councils are presented in this way: the Niceae one - as an annex to the New Testament, the Chalcedonian one - as a supplement to the Niceae one. From a chronological perspective, these are separate texts that are more than a century apart, but from the point of view of the concept of deuterosis, they are further clarifications that were necessary as new heresy has emerged. Each of the Christological

of inability to understand the entirety without understanding all its parts. Neither can individual parts be understood without knowing how they work in the overall composition that they form. 
Taką metodę interpretacji proponuje G. Strzelczyk. Jej niewątpliwą zaletą jest między innymi to, że pozwala na utrzymanie ciągłości z pierwotnymi tradycjami, jednocześnie aktualizując treść dogmatu dla naszej kultury i czasów współczesnych. Uważam, że w tym kontekście warto i powinno się stosować do pewnych regulacji, które definiowałyby zjawisko rozwoju niejako z zewnątrz i określałyby rozwój jako taki. Dobrą propozycją jest idea kryteriów rozwoju doktryny, jakie proponuje stosować kard. John Henry Newman. Pozwolę je sobie dla jaśniejszego oglądu tutaj wymienić, są to: zachowanie typu (trwanie istoty doktryny, pomimo zmiany jej formy), ciągłość zasad - niezmiennych reguł działających w nauce, asymilacja do siebie innych nauk, następstwo logiczne - zdolność wyrażania się zgodnego z zasadami logiki, uprzedzanie przyszłego rozwoju - odsłanianie pewnych efektów, które staną się widoczne po pewnym czasie, ciągłość z przebytym rozwojem, rozwój trwający w czasie ${ }^{22}$. Jeśli przeanalizuje się je u ważniej, okaże się, że cztery na siedem z tychże kryteriów dotyczy różnych aspektów idei ciągłości. Jedność z pierwotnym sensem, źródłem danej nauki stanowi fundamentalne prawo, które decyduje o tym, czy dane twierdzenie wciąż należy do początkowej myśli. Kiedy pojawia się zerwanie ciągłości w jakimś aspekcie, zaczyna się generować zjawisko zwane herezją. U J.H. Newmana figuruje ono pod nazwą wypaczenia. Myśl sprzeczna ze swoją ideą macierzystą w sposób oczywisty nie może być uznana za rozwijającą ją. Dlatego J.H. Newman poświęca tyle uwagi warunkom, jakie powinien spełniać poprawnie rozumiany rozwój. Aktualizacja dogmatów do czasów sobie współczesnych jest kluczowym zadaniem, przed jakim stoją teologowie, odkąd dzieje się ich historia. Jest ona (aktualizacja) konieczna, aby pozostały zachowane w niezmienionej treści (gdyż pozostawionym w przestarzałej względem nas formie prawdom wiary grozi niezrozumienie). Szczególnym kryterium jest następstwo logiczne. Aby było ono właściwie spełnione, konieczne jest podejście do dogmatu w całej jego rozciągłości i refleksja nad nim. Dodatkowo, jeśli zostanie podjęta rozumem oświeconym wiarą

${ }^{22}$ Międzynarodowa Komisja Teologiczna, op. cit., 299. 
decisions is, therefore, another act of revision, none of which exhaust the meaning of the Mystery ${ }^{21}$.

This is the method of interpretation proposed by Strzelczyk. Undoubtedly, its advantage is the fact that it provides a continuity with the original traditions, and simultaneously updates the content of dogma for our culture and modern times. In this context, it is worthwhile and one should comply with certain regulations which would define the phenomenon of development as if externally, and define development per se. The idea of criteria for the development of doctrine, as proposed by Cardinal John Henry Newman, constitutes a good proposal. To clarify matters, they are as follows: behaviour of the type (the essence of the doctrine remains, despite the change in its form), continuity of principles - unchanging rules of science, assimilation of other sciences, logical consequence - ability to express oneself according to the principles of logic, anticipation of future development - revealing certain effects that will become visible after some time, continuity with past development, development lasting over time. ${ }^{22}$ When analysed more thoroughly, four out of seven of these criteria are related to different aspects of the idea of continuity. Unity with its original meaning, the source of a given science, is a fundamental law which determines whether a given claim is still part of the original thought. When a break in continuity occurs in some aspect, a phenomenon called heresy begins to generate. Newman calls it distortion. A thought that runs counter to its original idea obviously cannot be considered to be developing it. That is why Newman pays as much attention to the conditions that a correctly understood development should meet. Updating dogmas to contemporary times is a key task faced by theologians ever since their history. Such an update is inevitable in order for them to remain unchanged (because the truths of faith, which are outdated to us, are in danger of being misunderstood). A particular criterion is the logical consequence. For it to be properly fulfilled, it is necessary

${ }^{21}$ Strzelczyk, G. op. cit., 8.

${ }^{22}$ International Theological Commission, op. cit., 299. 
będzie to dodatkową korzyścią - w ten sposób będzie mógł zostać zaktualizowany nie z zewnątrz, ale z samej rzeczywistości, jaką reprezentuje - wiary. Ścieżka, jaką proponuje J.H. Newman, to bardzo rozsądne wytyczne, których zachowywanie jest nieodzowne dla właściwej interpretacji uwspółcześniającej.

Krzysztof Góźdź, zajmując się tą problematyką, w swojej pracy Interpretacja dogmatów wychodzi od przekonania, że dogmat w teologii występuje wtórnie - jego pierwotnym środowiskiem jest wiara, a on sam słowem człowieka, który wyraża słowo Boga ${ }^{23}$. Tę myśl rozwija także Joseph Ratzinger, pisząc, że nauka chrześcijańska nie wyraża się zbiorem dających się od siebie oddzielić tez, ale istnieje w jedności symbolu, jak pierwotny Kościót nazwat wyznanie wiary przy chrzcie ${ }^{24}$. Kluczowe jest tutaj właśnie wyrażenie symbol. Z greckiego oznacza ono zbiegać się, składać, co nawiązuje prawdopodobnie do zwyczaju, wg którego dwie pasujące do siebie części jakiegoś przedmiotu (laski, pierścienia, tabliczki) stosowane są jako znak rozpoznawczy. Symbol więc pozwala się rozpoznać oraz jednoczy. Józef Ratzinger zauważa tutaj, że taki był właśnie pierwotny sens dogmatów: umożliwić wspólne wyznawanie Go, wspólne wielbienie Go ${ }^{25}$. Tak więc wiara pojedynczego człowieka jest to $\sigma 0 ́ \mu \beta 0 \lambda o v$ - niepełna cząstka, tworząca całość dopiero we wspólnocie. Jest nim w pewnym sensie także wiara całego Kościoła, która jest prawdziwa, tylko jeśli odnosi poza siebie ${ }^{26}$. Widać więc tutaj wyraźnie, na czym polega ta wtórność dogmatu, o jakiej pisze K. Góźdź. Ta więc wiara człowieka, która interpretuje Pismo, ma niezmienną postać (jak niezmienny jest symbol), ale jej przekazywanie odbywa się w konkretnym momencie w historii i w ten sposób jest od niej zależne. W tym miejscu powstaje pytanie, co jest czynnikiem bardziej istotnym podczas odbioru rzeczywistości zwanej dogmatem - zgodność z pierwotną tradycją, czy też warunki historyczne, w jakich się kształtowała? I jak

${ }^{23}$ K. Góźdź, art. cit., 14.

24 J. Ratzinger, Wprowadzenie w chrześcijaństwo, Kraków 2007, 95.

25 Ibidem, 96.

26 Ibidem, 97. 
to approach and reflect on dogma in its entirety. Furthermore, if it is taken up by reason enlightened by faith, it will be an additional asset, and in this way it can be updated not from outside, but from the very reality that it represents, i.e. the faith. The path that Newman suggests is a very sensible guideline, which it is essential to follow for a proper interpretation of modernity.

In his work „The Interpretation of Dogma”, Góźdź addresses this issue by starting from the conviction that dogma in theology is only secondary - its primary environment is faith, and the dogma itself is the word of man who expresses the word of God. ${ }^{23}$ This idea is also supported by Joseph Ratzinger, who writes that Christian science is not expressed by a set of separable theses, but exists in the unity of a symbol, as the original Church called the confession of faith in the Baptism creed. ${ }^{24}$ The key expression here is the symbol. From Greek it means to converge, fold, which probably refers to the custom that two matching parts of an object (of a stick, ring, plaque) are used as a hallmark. The symbol therefore allows you to recognize yourself and unite. Ratzinger notes here that this was precisely the original meaning of dogma: to enable us to confess to Him together, and to worship Him together ${ }^{25}$. Thus the faith of the individual is $\sigma 0 ́ \mu \beta 0 \lambda \sigma \nu$ - an incomplete particle, forming the entirety only in the community. In a sense, it is also the faith of the whole Church, which is true only if it is beyond itself. ${ }^{26}$ Therefore, the secondary dogma that Góźdź describes seems obvious here. Thus, the faith of man which interprets Scripture has an unchangeable form ( as the symbol is unchangeable), but its transmission takes place at a specific moment in history and is thus dependent on it. At this point, the question arises as to what is the more important factor in perceiving the reality called dogma - compliance with the original tradition, or the historical conditions in which it has been shaped? And how to

23 Góźdź, K. art. cit., 14.

24 Ratzinger, J. Introduction to Christianity, Kraków 2007, 95.

25 Ibidem, 96.

${ }^{26}$ Ibidem, 97. 
właściwie rozumieć owe warunki historyczne? Ta kwestia wydaje się być szczególnie ważna, zwłaszcza po przytoczonym przeze mnie sposobie interpretacji G. Strzelczyka. Przypuszczam, że przedstawienie myśli K. Góździa powinno uzupełnić jego metodę interpretacyjną. Za podstawę rozwoju dogmatów w poprzednim tekście uznany jest sam Bóg, jako res - przedmiot wiary i gwarant jej rozwoju. Natomiast K. Góźdź w tej kwestii kładzie szczególny nacisk na udział człowieka w tym procesie. Ponieważ zmienne są warunki, w jakich przebywa ludzkość, staje się to motorem procesu coraz to nowszych interpretacji, których celem jest zachowanie sensu pierwotnego i prawdziwego. W tym kontekście zauważa zjawisko dwóch przeciwstawnych sobie ruchów: rozwoju i redukcji. Rozumiane są jako kolejno występującerozszerzenie oraz powrót do pierwotnej prostoty. U G. Strzelczyka w procesie interpretacji dogmatów daje się zauważyć szczególnie ważne spostrzeżenie - ideę pociągającego wszystko ku sobie res, jako telos, który jest transcendentny w stosunku do interpretowanego tekstu. Jest to szczęśliwe założenie, gdyż dzięki temu głównego klucza rozumienia prawd objawionych nie można sprowadzić do jednego z jego elementów ${ }^{27}$. Jednak uzupełniającą to słuszne stanowisko może być myśl Ojców greckich, którą przytacza K. Góźdź: chrześcijaństwo jest Wcieleniem, zapoczątkowanym przez Jezusa z Nazaretu, ale nie na Nim zakończonym, lecz trwającym aż do skończenia świata. Główna przyczyna dogmatów jawi się tutaj przede wszystkim jako immanentna, osobowa obecność. Jej skutkami są ponawiane raz po raz próby wyrażenia tego, w co wierzy wspólnota. Podobnie też rozumiane jest Objawienie nie tylko jako przeszłe wydarzenie, ale jako ciągle aktualne, teraźniejsze misterium. Jest to jedną z przytoczonych przez K. Góździa trzech tez Josepha Ratzingera: że Objawienie i Pismo nie są tożsame, iż Pismo ma różne znaczenie w Starym Testamencie i w Nowym, oraz Jezus Chrystus - jako objawienie Boga, ciągle trwające i żywe ${ }^{28}$. Kościół jako wspólnota przechodzi metamorfozę, ale jako mistyczne Ciało Chrystusa pozostaje tą samą

27 G. Strzelczyk, op. cit., 6-7.

${ }^{28}$ K. Góźdź, art. cit, 5-6. 
understand these historical conditions properly? This question seems to be particularly important, especially after the aforementioned Strzelczyk's interpretation. The author of this paper supposes that the presentation of Góźdź's thoughts should complement his method of interpretation. God Himself is considered to be the basis for the development of dogmas in the previously cited text, as res, this is the object of faith and the guarantor of its development. In this respect, however, Góźdź places particular emphasis on human participation in this process. Since the conditions in which mankind lives are changing, it is becoming the driving force behind a process of ever newer interpretations aimed at preserving the original and true meaning. In this context, he notes the phenomenon of two opposing movements: development and reduction. They are understood as occurring sequentially, extension and a return to original simplicity. In Strzelczyk's interpretation of dogma, a particularly important observation can be seen which is the idea that res attracts everything towards itself, as telos that is transcendent in relation to the text being interpreted. This is a fortunate assumption, as it makes the main key to understanding the revealed truths impossible to be diminished to one of its elements ${ }^{27}$. However, the thought of the Greek Fathers, quoted by Góźdź may complement this rightful position, and it says that Christianity is Incarnation, initiated by Jesus of Nazareth, but never completed on Him, it rather lasts until the end of the world. The main cause of dogma here appears above all as immanent, personal presence. Its effects are repeated attempts to express what the community believes in. Revelation is also understood in a similar way, not only as a past event, but as an ever-present mystery. This is one of the three theses of Joseph Ratzinger cited by Góźdź, saying that Revelation and Scripture are not identical; Scripture has different meanings in the Old Testament and in the New Testament, and Jesus Christ is a revelation of God, still alive and ever-lasting ${ }^{28}$. The Church, as a community, is undergoing a metamorphosis, but

${ }^{27}$ Strzelczyk, G. op. cit., 6-7.

${ }^{28}$ Góźdź, K. art. cit, 5-6. 
osobą - musi więc posiadać pewne konstytutywne dla siebie cechy niezmienne - jedną z nich jest z pewnością jego wiara. Dogmaty tejże wiary (w ich sensie szerokim i wielowątkowym) określiłabym jako jej DNA. Istnieją w świadomości Kościoła od początku, ich rozumienie jest stale rozwijane, pozostają jednak niezmienne w swej istocie. Tu dotyka się elementu pierwotnych tradycji, które w swej treści pozostały te same od pierwszych wieków aż do dziś. Dogmat jako taki sam jest interpretacją - autorytatywną Pisma Świętego. Joseph Ratzinger rozumie to jako obustronną relację. Pismo należy czytać w kierunku dogmatu, ale też z dogmatem powinno się powracać do jego pierwotnych źródeł i w ich świetle rozumieć ${ }^{29}$.

Marzeniem jest wypracowanie idealnej metody interpretacyjnej, która we właściwych proporcjach będzie łączyć w sobie studium historyczne, egzegezę, tradycje teologiczne, perspektywę wiary i wszystkie składające się na pełne poznanie czynniki. Pytanie brzmi: czy można takową metodę w ogóle stworzyć? Moim zdaniem nie $\mathrm{i}$ jest to wbrew pozorom pozytywny aspekt pracy teologa dogmatyka. Jedną z najbardziej fascynujących cech dogmatów jest to, że jako twierdzenia nigdy nie wyczerpią rzeczywistości, o której mówią. Dzięki temu teologia ma przed sobą pole do rozwoju, a teolodzy - nieskończone możliwości doskonalenia swoich sposobów pracy. Żadna metoda nigdy nie będzie idealna, choć można stworzyć i zapewne stworzono wiele bardzo dobrych, które naświetlają aspekty prawd pozostające do tej pory w cieniu. Przykładowo G. Strzelczyk pod koniec swego tekstu ${ }^{30}$ przedstawia pewną analogię dogmatu jako granicy okalającej obszar, na którym poznanie Boga jest wspótbrzmiace z tym, kim jest On sam w sobie (telos). W sensie szerokim nie jest to mur nie do przekroczenia, ale płynny zielony pas, na którym porozmieszczane są posterunki - ścisłe twierdzenia, ustanawiane przez służby graniczne w miejscach szczególnego zagrożenia świadomego (lub nie) przekroczenia granicy. Ustanowienie jed-

29 J . Ratzinger, Tradition, w: J . Ratzinger, Opera Omnia, t. IX/1: Wiara w Piśmie i Tradycji. Nauka o zasadach teologicznych, Lublin 2018, 360.

${ }^{30}$ G. Strzelczyk, op. cit., 9. 
as the mystical Body of Christ, it remains the same person, so it must have certain constitutive features that are unchangeable, and one of these is certainly faith. The author believes that the dogma of such faith (in its broad and multi-threaded sense) can be described as its DNA. They exist in the consciousness of the Church from its very beginning, their understanding is constantly being developed, but they remain unchanged in their essence. Here we approach an element of the original traditions, which in their content have remained the same since the first centuries. The dogma as such is an interpretation - an authoritative interpretation of Scripture. Joseph Ratzinger understands it as a reciprocal relationship. Scripture should be read in the direction of dogma, but with dogma one should also return to its original sources and understand it in their light. ${ }^{29}$

The dream is to develop an ideal method of interpretation, which will combine historical study, exegesis, theological traditions, the perspective of faith and all the factors that make up the full knowledge. The question is whether such a method is possible by any means? The author of this paper believes it is not, and contrary to appearances, it is the positive aspect of the work of a dogmatic theologian. One of the most fascinating features of dogma is that as statements they never exhaust the reality they speak of, and this gives theology room for development, and theologians have endless opportunities to improve their ways of working. No method will ever be perfect, although many very good ones can be created, and probably have been created, which highlight aspects of the truths that have been left in the shadows so far. For example, at the end of his text, ${ }^{30}$ Strzelczyk presents a certain analogy - dogma as the boundary surrounding the area where the cognition of God is in harmony with who He is in himself (telos). Broadly speaking, it is not a wall not to be crossed, but a liquid green belt where the posts are located, like strict statements made by the customs services at places of particular risk of conscious (or not)

${ }^{29}$ Ratzinger, J . Tradition, in: Ratzinger, J . Opera Omnia, vol. IX/1: Wiara w Piśmie i Tradycji. Nauka o zasadach teologicznych, Lublin 2018, 360.

${ }^{30}$ Strzelczyk, G. op. cit., 9. 
nego takiego punktu powoduje koncentrację przemytników w innym obszarze, co wymaga ustanowienia kolejnego tak, by harmonizował z innymi a jednocześnie twardo określał granicę (relektura istniejącej sytuacji! $)^{31}$. Jest to bardzo sugestywne nakreślenie rzeczywistości dogmatycznej, z którym bardzo się zgadzam.

Dlatego uważam, że warto wypróbować ideę przeszczepienia metody interpretacyjnej P. Beauchampa na grunt dogmatyki w praktyce. Dla przykładu jej zastosowania przenalizuję wg jej kryteriów naukę Kościoła o stworzeniu.

Dogmat ten jest rzeczywistością prastarą, oczywistością dla wyznawców judaizmu i chrześcijaństwa. Rozwój rozumienia tej doktryny w przypadku katolików jest przykładem bardzo złożonego procesu, w którym biorą udział nie tylko herezje stricte dot. tematu (walka z nimi), powstawanie nowych koncepcji teologicznych czy pogłębiana egzegeza Pisma Świętego, ale także polemika z błędami nie godzącymi ściśle w prawdę o kreacji, czy rozwój nauk przyrodniczo - matematycznych. Na progres rozumienia dogmatu o stworzeniu chcę spojrzeć na płaszczyźnie (wybranych) wypowiedzi Magisterium Kościoła oraz podległych mu instytucji.

Pierwszą wypowiedzią Kościoła tej rangi jest Sobór Nicejski z 325 r. Przełomowym jego osiągnięciem jest opracowanie symbolu wiary wspólnego dla wszystkich wiernych Kościoła. Interesujący mnie temat zaznaczony jest tam klarownie: Stworzycielem wszystkich rzeczy widzialnych i niewidzialnych jest Ojciec, który swego dzieła dokonał przez Syna (przez którego wszystko się stało, co jest $w$ niebie i co jest na ziemi ${ }^{32}$ ). Na pierwszy rzut oka widać następujące ustalenia: istniejący świat został stworzony przez Boga i dzieli się na rzeczywistość materialną oraz duchową. Rola kreatora należy do Ojca, który stwarza przez Syna i przez Niego zbawia. Sobór Konstantynopolitański w 381 r. doprecyzowuje: Duch Święty nie należy do zbioru stworzeń ${ }^{33}$. On działał w poprzednich etapach objawienia,

\footnotetext{
${ }^{31}$ Ibidem, 9-10.

32 I Sobór Nicejski, Wyznanie wiary 318 Ojców.

${ }^{33}$ I Sobór Konstantynopolitański, Wyznanie wiary 150 Ojców.
} 
border crossing. The establishment of one such checkpoint results in a concentration of smugglers in another area, which requires the establishment of another one in order to harmonise with the others and at the same time to define the border firmly ( to review the existing situation!). ${ }^{31}$ This is a very suggestive outline of dogmatic reality the author hereof definitely agrees with.

Therefore, the author believes it is worth trying out to transplant the Beauchamp interpretation method into practice. To illustrate its application, the Church's teaching on creation will be analysed below according to its criteria.

This dogma is an ancient reality, obvious to the followers of Judaism and Christianity. The development of an understanding of this doctrine in the case of Catholics is an example of a very complex process in which not only heresies strictly related to the subject (the fight against them), the emergence of new theological concepts or an in-depth exegesis of Holy Scripture are involved, but also a polemic with errors that do not strictly reconcile the truth about creation or the development of natural and mathematical sciences. The author intends to reflect on the progress of understanding the dogma of creation at the level of (selected) statements of the Church Magisterium and its subordinate institutions.

The first statement of the Church of this rank is the Council of Nicaea of 325. Its breakthrough achievement is the development of a symbol of faith common to all the faithful of the Church. The theme the author considers relevant is clearly stated there: The Creator of all things visible and invisible is the Father, who did his work through his Son (through whom all things came to be, both those in heaven and those in earth ${ }^{32}$ ). What can be clearly identified is that the existing world was created by God and is divided into material and spiritual reality. The role of the creator belongs to the Father, who creates through the Son and saves through him. The Council of Constantinople in 381 clarifies that The Council of Constantinople

${ }^{31}$ Ibidem, 9-10.

${ }^{32}$ First Council of Nicaea, Profession of Faith of the 318 Fathers. 
teraz zaś formuje Kościół, uobecnia w nim Chrystusa. Symbol ma strukturę trynitarną, każda z trzech jego części przedstawia jedną Osobę poprzez odmienne przypisywane jej działania. Konstrukcja ta ukazuje, że stworzenie jest podstawowym miejscem objawienia. Wyciągnąć jednak można z Symbolu Konstantynopolitańskiego także bardziej ogólne wnioski. Przede wszystkim przedmiotem wiary nie są tezy na temat świata jako takiego, ale jest nim Bóg, jako rzeczywistość osobowa ${ }^{34}$. Stwarza On w sposób zupełnie suwerenny. W związku z tą wiarą człowiek przyznaje światu ogólna ocenę stworzenia ${ }^{35}$. Oznacza to, że doktryna o kreacji jest transcendentalnym spojrzeniem na uniwersum w kontekście relacji do Boga ${ }^{36}$. Odnośnie do tej relacji, G. Müller czyni brzemienne w skutkach spostrzeżenie. Słowa Credo utożsamiają Stwórcę wszystkiego z Bogiem przymierza, zwłaszcza przez określenie Ojciec wszechmogacy $(\mathrm{Rdz} 17)^{37}$. Stąd wyprowadzony jest wniosek, że wiara w Boga Stwórcę pochodzi z doświadczenia okazywanej przez niego mocy w historii, świecie i życiu danego człowieka. W świetle koncepcji interpretacji G. Strzelczyka jest to arche tego dogmatu, które należało znaleźć i zdefiniować.

W kolejnych stuleciach Kościół konsekwentnie potwierdza i doprecyzowuje swoją naukę o stworzeniu świata. Podczas synodu konstantynopolitańskiego odrzuca koncepcję „orygenistów”, że Bóg stworzył jedynie tyle, ile mógł, ponieważ Jego moc jest ograniczona $^{38}$. Potępiając pryscylianów w 561 r. podczas synodu w Bradze, wyklina przekazujących następujące opinie:

${ }^{34}$ G.L. Müller, Dogmatyka katolicka, Kraków 2015, 187.

35 Ibidem.

${ }^{36}$ Ibidem.

${ }^{37}$ Cf. Ibidem.

${ }^{38}$ Breviarium Fidei, Synod Konstantynopolitański, por. BF, V, 1. 
in 381 clarifies that the Holy Spirit does not belong to the collection of creatures ${ }^{33}$. He acted in the previous stages of revelation, but now he forms the Church and makes Christ present in it. The symbol has a Trinitarian structure, each of its three parts represents one Person through different actions attributed to him. This structure shows that creation is the primary place of revelation. However, more general conclusions can also be drawn from the Constantinople's Symbol. Above all, the subject of faith is not the world as such, but God, as a reality of person ${ }^{34}$. He creates in a completely sovereign way. In connection with this faith, man gives the world an overall assessment of creation $^{35}$. This means that the doctrine of creation is a transcendental view of the universe in the context of relations to $\mathrm{God}^{36}$. Regarding this relationship, Müller makes an important observation, saying the words of the Credo identify the Creator of all things with the God of the covenant, especially by the term Almighty Father (Genesis 17) ${ }^{37}$. This leads to the conclusion that faith in God the Creator comes from the experience of his power in the history, world and life of a person. In the light of Strzelczyk's interpretation of this dogma, it is arche of this dogma, which needed to be found and defined.

In the following centuries the Church has consistently confirmed and clarified its teaching about the creation of the world. During the Constantinople's Synod the concept of the ,Origenists' was rejected stating that God created only as much as he could, since his power is limited ${ }^{38}$. While condemning the Priscillian at the First Council of Braga of 561, supporters of the following opinions were cursed:

33 First Council of Constantinople, Exposition of Faith of the 150 Fathers.

${ }^{34}$ Müller, G.L. Catholic Dogmatics for the Study and Practice of Theology, Herder \& Herder; Reprint edition (October 1, 2017).

35 Ibidem.

36 Ibidem.

${ }^{37}$ Cf. Ibidem.

38 Breviarium Fidei, Synod of Constantinople, see BF, V, 1. 
(kan. 5): dusze ludzkie i aniołowie pochodza z substancji Bożej

(kan. 7): Diabet nie byt najpierw dobrym aniotem stworzonym przez Boga, nie miat żadnego stwórcy oraz jest substancja lub zasada zła

(kan. 8): diabet tworzy dusze i wtasna moca wyrzadza szkody światu i ludziom

(kan. 9): Dusze i ciała ludzkie sa poddane ruchom ciat niebieskich

(kan. 11): Należy odrzucić małżeństwo; rodzenie dzieci jest czymś wstrętnym

(kan. 12): ciało ludzkie stworzyt diabet; nie ma jego zmartwychwstania

(kan. 13): utworzenie wszelkiego ciała nie jest dziełem Boga, lecz diabła ${ }^{39}$

Na podstawie tekstów Synodu w Bradze jasno też widać rozwój interpretacji własnej nauki Kościoła. Usunięte zostają wszelkie wątpliwości na temat natury rzeczy stworzonych - wszystko, co istnieje jest z natury dobre. G. Müller nazywa to odpowiednikiem motywu stworzenia, jaki dobroć Boga znajduje w swoich tworach ${ }^{40}$.

Kolejną wypowiedzią zawierającą istotne ustalenia na interesujący mnie temat jest konstytucja $O$ wierze katolickiej IV Soboru Laterańskiego. Rozpoczyna się ona dłuższym wywodem trynitologicznym o jedyności oraz troistości Boga, w tym o pochodzeniach Osób. Stąd następuje płynne przejście do nauki o stworzeniu: Bóg Trójjedyny zostaje nazwany jedną Zasadą wszechświata, Stwórca wszystkiego, co widzialne i niewidzialne ${ }^{41}$. Określenie to jest wymierzone w odradzające się za sprawą katarów tendencje manicheistyczne. Pewne znaczenie ma też fakt, że w tej konstytucji po raz pierwszy oficjalnie zostaje użyte sformułowanie ex nihilo w kontekście stworzenia.

39 Breviarium Fidei, Synod w Bradze, por. BF, V, 2-8.

${ }^{40}$ G.L. Müller, op. cit., 193.

${ }^{41}$ Por. IV Sobór Laterański, Konstytucja o wierze katolickiej. 
(235 5): human souls or angels have arisen from the substance of God

(235 7): the devil was not first a good angel made by God, and that his nature was not a work of God, but says that he came forth from darkness, and does not have any author of himself, but is himself the origin and substance of evil

(235 8): the devil made some creatures in the world and by his own authority the devil himself causes thunder and lightning, and storms and spells of dryness

(235 9): human souls [al. souls and human bodies] are bound by a fatal sign [al. by fatal stars]

(235 11): human marriage [should be condemned]; [there is] a horror of the procreation of living bodies

(235 12): the formation of the human body is a creation of the devil, (...) and for this reason [there is no] resurrection of the body

(235 13): the creation of all flesh is not the work of God, but belongs to the wicked angels ${ }^{39}$

On the basis of the texts of the Synod of Braga, one can also clearly see the development of interpretation of the Church's own teaching. All doubts about the nature of created things - everything that exists is inherently good - are removed. Müller calls this the equivalent of the motif of creation that the goodness of God finds in his creations ${ }^{40}$.

Another statement containing important findings on a subject of interest to the author of this paper is the Constitutions on the Catholic Faith of the Fourth Lateran Council. It begins with a longer Trinitological argumentation about the uniqueness and the trinity of God, including the origins of Persons. Hence the smooth transition

39 Breviarium Fidei, Synod of Braga, https://sensusfidelium.us/the-sources-of-catholic-dogma-the-denzinger/council-of-braga-ii-561 -anathemas-against-heretics-especially-the-priscillianists/

${ }^{40}$ Müller, G.L. op. cit., 193. 
Sobór podejmuje też temat pochodzenia zła, które jest wynikiem wyboru wolnej woli rozumnych bytów - szatana oraz człowieka. Po tym występuje też wykład chrystologii, będącej spuścizną rozwoju interpretacji Objawienia przez poprzednie Sobory oraz teologów. Nie pozostaje to bez znaczenia dla poruszanego przeze mnie dogmatu. H. Wagner zauważa, że chrystologia nie rozważa szczególnego przypadku człowieczeństwa, ale ten, który jest dla tej natury wzorcowy ${ }^{42}$. Zaobserwować można tutaj ciekawą drogę progresu dziedzin teologicznych, rysuje się ona mniej więcej tak: kreatologia - chrystologia antropologia. Nie jest to rzecz jasna porządek, będący całkowitym obrazem ich rozwoju i obowiązujący w każdym aspekcie, ale ogólny ilustrujący go schemat.

Tak więc w Chrystusie człowieczeństwo osiąga doskonałość, a skoro antropologia jest zwieńczeniem kreatologii (gdyż istocie ludzkiej poddane zostały inne stworzenia i jest ona obrazem swego Stwórcy ${ }^{43}$ ) to należy wziąć pod uwagę także obecność tychże fragmentów w kontekście nauki o stworzeniu. Dlatego zaznaczam, że fragment chrystologiczny pojawiający się w konstytucji $O$ wierze katolickiej również nie pozostaje bez znaczenia dla poruszanego przeze mnie dogmatu. Ponadto, IV Sobór Laterański akt stworzenia wyprowadza przede wszystkim z wszechmocy Bożej, na którą kładzie nacisk. Okaże się to interesującym akcentem w świetle następnych tekstów.

Mam tutaj na myśli zwłaszcza Sobór Florencki z 1442 r. Podobnie jak poprzedni, walczy on z nauką manichejską ${ }^{44}$ natomiast szczególnie podkreśla nie tyle wszechmoc, co dobroć Boga Stwórcy, a także Jego wolną wolę w akcie stworzenia. W efekcie tego zaistniałe byty są dobre, ale zmienne, gdyż powstały ex nihilo ${ }^{45}$. Nacisk jest położony na naturalne dobro wszystkich bytów - zarówno cielesnych, jak i duchowych, a także na jedyność ich Stworzyciela oraz Inicjatora

42 H. Wagner, op. cit., 360.

43 Ibidem.

44 G.L. Müller, op. cit., 191.

45 Breviarium Fidei, Sobór Florencki, por. BF, V, 14. 
to the science of creation: The Triune God is the one principle of the universe, Creator of all things invisible and visible ${ }^{41}$. The term is aimed at the tendencies of Manichaeism that are being revived by the Catharism. It is also of some importance that the Constitutions officially use the term ex nihilo referring to creation for the first time in history. The Council also addresses the subject of the origin of evil, which is the result of the choice of the free will of rational beings, Satan and man. This is followed by a lecture in Christology, which is the legacy of the development of Revelation's interpretation by previous Councils and theologians. It is also relevant to the dogma the author of this paper addresses. Wagner notes that Christology does not consider a particular case of humanity, but one that is exemplary for this nature. ${ }^{42}$ Here one can observe an interesting way of the progression of theological disciplines, it is more or less as follows: creativity - Christology - anthropology. It is not, of course, an order that is a complete picture of their development and valid in every aspect, but a general scheme that illustrates it.

Thus, in Christ, humanity achieves perfection, and since anthropology is the culmination of creativity (since other creatures have been subjected to human beings and it is an image of its Creator ${ }^{43}$ ), the presence of these passages in the context of the science of creation must also be considered. Therefore, it should be noted that the Christological fragment appearing in the Constitutions on the Catholic Faith is also relevant to the dogma discussed here. The Fourth Lateran Council, moreover, draws the act of creation above all from God's omnipotence, which it emphasises. This proves to be an interesting focus in the light of the next texts.

The author particularly refers to the Council of Florence in 1442. Similarly to the previous one, it fights against the Manichaean teachings, but it particularly emphasises not so much omnipotence

${ }^{41}$ See Fourth Lateran Council, Constitutions. https://sourcebooks.fordham.edu/ basis/lateran4.asp

42 Wagner, H. op. cit., 360.

43 Ibidem. 
Starego i Nowego Testamentu ${ }^{46}$. Dobra natura istot przygodnych jest wynikiem dobroci ich Autora, którą ukazują jego twory. Istnieje jeden Stwórca całego świata, a ponieważ jest dobry - wszystkie byty z natury swej takie są.

V Sobór Laterański odwołuje się do kanonu Klemensa V na Soborze w Vienne w 1311 r. i nie orzeka ogólnie o stworzeniu, ale bardziej szczegółowo - wypowiada się na temat antropologii. Potępia teorię, że dusza ludzka jest śmiertelna, a także opinię, że może być ona wspólna dla całego rodzaju ${ }^{47}$. Według analogii G. Strzelczyka ${ }^{48}$ jest to kolejny posterunek na pasie granicznym okalającym obszar ortodoksji. Zamyka on drogi wielu spekulacji antropologicznych w teologii, które mogłyby jednakowoż prowadzić donikąd. Tym samym jest również wytyczeniem ścieżki dla prawdziwego rozwoju nauki o człowieku.

Tym ciekawsze dla mojego wywodu są stwierdzenia synodu w Kolonii, który odbył się w 1860 r. G. Müller podaje, że opinie katolickich teologów A. Günthera i G. Hermesa, którzy zbytnio oparli się na filozofii Kanta oraz Hegla przyczyniły się do stanowczego wyrażenia sprzeciwu wobec deizmu, panteizmu oraz heglowskiej koncepcji stającego się Boga ${ }^{49}$. Uczyniono to jednak w sposób korespondujący $\mathrm{z}$ dotychczasowym podejściem teologicznym. Postawiono bowiem następujące twierdzenia:

- Bóg istnieje sam w sobie, jest niezmienny, nie staje się wraz z powstawaniem świata

- Bóg stwarza świat z własnej woli, bez wewnętrznej konieczności i zewnętrznego przymusu, dla udzielenia swojej dobroci mógt stworzyć także inny świat

- świat zostat przez Boga stworzony w czasie

- Celami stworzenia sa szczęście człowieka i objawienie chwaty Boga, jak również Jego doskonatości, przede wszystkim Jego madrości, potęgi, dobroci.

\footnotetext{
46 Ibidem.

${ }^{47}$ Breviarium Fidei, V Sobór Laterański, por. BF, V, 36.

48 G. Strzelczyk, op. cit., 9.

${ }^{49}$ G.L. Müller, op. cit., 191.
} 
as the goodness of God the Creator, as well as His free will in the act of creation. As a result, the creatures that have emerged are good but changeable, because they have emerged ex nihilo44. The emphasis is on the natural good of all beings, both physical and spiritual, as well as the uniqueness of their Creator and initiator of the Old and New Testaments. ${ }^{45}$ The good nature of incidental beings is the result of their author's goodness, which is shown by his/her creations. There is one Creator of the whole world, and because he is good, all beings are good by nature.

The Fifth Lateran Council refers to the canon of Clement $\mathrm{V}$ at the Council of Vienne in 1311 and does not rule on creation in general, but more specifically, it speaks of anthropology. It condemns the theory that the human soul is mortal, as well as the opinion that it can be shared by the whole genus. ${ }^{46}$ According to Strzelczyk's analogy, ${ }^{47}$ it is yet another post within the border strip surrounding the area of orthodoxy. It hinders many anthropological speculations in theology, which could nevertheless lead nowhere. It is thus also a pathway for the true development of human science.

What is even more interesting as regards the paper hereof are the statements of the Synod in Cologne, which took place in 1860. Müller points out that the opinions of the two Catholic theologians, Günther and Hermes, who had supported Kant's and Hegel's philosophy too much, contributed to a firm opposition to deism, pantheism and the Hegelian concept of the becoming of God $^{48}$. However, it was done in a way that is consistent with the theological approach taken to date. The following assumptions were made:

- God exists in Himself, He is unchangeable, God could not have created the world out of Himself

${ }^{44}$ Breviarium Fidei, The Council of Florence, see BF, V, 14.

45 Ibidem.

46 Breviarium Fidei, Fifth Lateran Council, see BF, V, 36.

47 Strzelczyk, G. op. cit., 9.

${ }^{48}$ Müller, G.L. op. cit., 191. 
- synod rozróżnia Gloria Dei subiectiva: modlitwa, dziękczynienie, wielbienie Boga przez czlowieka oraz gloria Dei obiectiva: ukazywanie się Boga w swych dziełach..$^{50}$

Kreatologia nie podaje $\mathrm{w}$ pierwszej kolejności twierdzeń na temat stworzenia, ale na temat jego Autora. On jest przedmiotem nauki i wiary, stworzenie występuje dopiero na drugim miejscu, jako noszące w sobie Objawienie. Jednakowoż twierdzenia o Bogu pozwalają na wysnucie wniosków dotyczących uniwersum. Powstało w dwojakim celu: szczęścia ludzi (które to stworzenia są szczytem stworzenia) oraz objawienia chwały Boga. U Hegla Absolutem jest idea, która myśli sama siebie we wszystkim, co realne, także w przyrodzie, natomiast poznaje siebie w człowieku, nazywanym z tego względu samoświadomością ${ }^{51}$. Choć synod walczy z panteizmem oraz koncepcjami heglowskimi, to jednak nie przeakcentowuje przeciwnych aspektów teologii (np. o transcendencji Boga), ale ukazuje właściwe zastosowanie nauki o obecności Boga w stworzeniu, rozróżniając Gloria Dei obiectiva oraz Gloria Dei subiectiva.

I Sobór Watykański odnosi się do tych samych twierdzeń w konstytucji Dei Filius ${ }^{52}$. Naukę na temat dogmatu o stworzeniu wykłada już w pierwszym rozdziale tego dokumentu O Bogu Stworzycielu wszystkich rzeczy - ten adekwatny tytuł zdradza, jaka jest zasadnicza treść tej części konstytucji. Połowę jej, pierwsze dwa punkty zajmuje wykład o Bogu jako takim. W odpowiedzi na panteistyczne koncepcje najmocniejszy nacisk Sobór kładzie na Boską transcendencję. W odniesieniu do świata Bóg nazwany jest Stworzycielem oraz Panem nieba i ziemi. Przez oba te określenia punkt 16 ukazuje jedność z bardzo długą tradycją, zakorzenioną w Biblii. Kolejny punkt natomiast jest bardziej filozoficzny - orzeka o świecie poprzez odróżnienie go od jego Stwórcy, którego nazywa zupetnie niezłożona $i$ niezmienna duchowa substancja, rzeczowo i istotowo różna od

50 Synod w Kolonii, cyt. za: G.L. Müller, op. cit., 191.

${ }^{51}$ C. Valverde, Antropologia filozoficzna, Poznań 1998, 78-79.

52 G.L. Müller, op. cit., 191. 
- God creates the world out of His own free will, without internal necessity and external coercion, for His goodness He could also create another world.

- the world was created by God in time

- The aims of creation are the happiness of man and the revelation of the glory of God, as well as His perfection, and above all His wisdom, power, goodness.

- The synod distinguishes between Gloria Dei subiectiva: prayer, thanksgiving, worship of God by man, and gloria Dei obiectiva: the appearance of God in his works. ${ }^{49}$

Creatology does not primarily claim to be about creation, but about its author, who is the subject of science and faith, the act of creation comes only after that, the one bearing Revelation. However, the claims about God allow us to draw conclusions about the universe, which has a twofold purpose: the happiness of human beings (which are the summit of creation) and the revelation of the glory of God. Hegel's Absolute is an idea which thinks of itself in everything that is real, including nature, but which recognizes itself in man, therefore called self-awareness. ${ }^{50}$ Although the Synod fights against Pantheism and the Hegelian concepts, it does not overstate the opposite aspects of theology (e.g. about God's transcendence), but shows how to apply the science of God's presence in creation, distinguishing between Gloria Dei obiectiva and Gloria Dei subiectiva.

The First Vatican Council refers to the same statements in the Constitution Dei Filius ${ }^{51}$. The dogma of creation is already taught in the first chapter of this document, About God the Creator of All Things, and as such, this title reveals what is the essential content of this part of the Constitution. Half of it, the first two points of it is a lecture on God as such. In response to the pantheistic concepts, the Council places the strongest emphasis on Divine transcendence. In relation to the world, God is called the Creator and Lord of heaven

49 Synod of Cologne, op. cit: Müller, G.L. op. cit., 191.

${ }^{50}$ Valverde, C. Philosophical Anthropology, Polish edition: Poznań 1998, 78-79.

${ }^{51}$ Müller, G.L. op. cit., 191. 
świata $^{53}$. Bóg jest przede wszystkim Bytem odmiennym od świata nieskończonym ontologicznym dystansem. Następnie wykładany jest kontekst i powód stworzenia, które uczynił: dla ukazania swej doskonatości poprzez dobra przydzielone stworzeniom najzupetniej wolna wola ${ }^{54}$. Do przedstawienia tego dogmatu użyta jest definicja IV Soboru Laterańskiego, z której jasno wynika, że stworzenie dokonane zostało w czasie i z niczego. Występuje też tradycyjny podział na byty duchowe, cielesne oraz ludzkie. Wszechświat przedstawiony jest ogólnie, konstytucja koncentruje się na ukazaniu jego nietożsamości z Bogiem. Tym, co łączy Stwórcę i stworzenie jest inicjatywa, którą punkt 19 nazywa opatrznością. Bóg znajdując się na zewnątrz uniwersum, jednocześnie utrzymuje je $\mathrm{w}$ istnieniu ${ }^{55} \mathrm{i}$ angażuje się w jego dzieje, władając wszystkim z dobrociq ${ }^{56}$. Nietrudno spostrzec, że dzięki temu jest On obecny w świecie także immanentnie, ale dlatego, że będąc na ontologicznie na zewnątrz, decyduje się weń wejść (wraz z chwilą stworzenia). Taką perspektywę zdaje się prezentować Dei Filius. Co jest najbardziej charakterystyczne w podejściu do kreatologii Vaticanum I, to brak połączenia jej z soteriologią i chrystologią. M. Kowalczyk zapewne słusznie sugeruje, że takie postawienie tematu ma za zadanie pokazać, że stworzenie świata można rozpatrywać także jako fakt rozumowo udowadnialny - nie tylko jako dogmat wiary ${ }^{57}$. Nie jest to rzecz jasna całość teologii stworzenia, jaką Kościół podaje w tym dokumencie, ale najistotniejsze treści.

Wejściu Kościoła w wiek XX, co znamienne, towarzyszy rozwój egzegezy i interpretacji Pisma Świętego. Szczególną pracę pod tym względem widać, jeżeli chodzi o pierwsze rozdziały Księgi Rodzaju. W perspektywie niniejszej pracy określić to można jako powrót dogmatu do swoich źródeł, naturalny kierunek jego odczytywania

\footnotetext{
53 I Sobór Watykański, Dei Filius.

${ }^{54}$ Ibidem.

${ }_{55}$ H. Wagner, op. cit., 396.

56 Ver Sab 8,1.

57 M. Kowalczyk, Traktat o stworzeniu.
} 
and earth. By both these terms, paragraph 16 shows unity with a very long tradition, rooted in the Bible. The next point, however, is more philosophical, and defines the world by distinguishing it out from its Creator, whom it calls one, singular, completely simple and unchangeable spiritual substance, (...) distinct from the world..$^{52}$ God is, above all, a Being that is different from the world with an infinite ontological distance. Then the context and reason for the act of creating he made is clarified, i.e. to manifest his perfection by the good things which he bestows on what he creates, by an absolutely free plan ${ }^{53}$. In order to present this dogma, the definition of the Fourth Lateran Council is used, from which it is clear that creation was made in time and from nothingness. There is also the traditional division into spiritual, bodily and human beings. The universe is presented in general terms, the constitution is focused on showing its identity with God. What unites the Creator and the creation is the initiative, which paragraph 19 calls providence. God, being outside the universe, at the same time maintains it in existence ${ }^{54}$ and commits himself to its history, as he is a marvelous governor over everything in between. ${ }^{55}$ One can easily see that this makes him present in the world immanently, yet ontologically outside, he decides to enter it (along with the moment of creation). This is the perspective that Dei Filius seems to present. What is most characteristic in the approach to Vaticanum I creatology is its lack of connection with soteriology and Christology. Kowalczyk seems to be right in his suggestion that such an approach to the subject is intended to show that the creation of the world can also be considered as a fact that can be reasonably proven, not only as a dogma of faith. ${ }^{56}$ This is not, of course, the whole

\footnotetext{
52 The First Vatican Council, Dei Filius.

${ }^{53}$ Ibidem.

${ }_{54}$ Wagner, H. op. cit., 396.

55 Wisdom 8:1, Common English Bible (CEB) Copyright (C) 2011 by Common English Bible

56 Kowalczyk, M. Traktat o stworzeniu.
} 
i interpretacji. ${ }^{58}$ Dekret Komisji Biblijnej, utworzonej przez Leona XIII stwierdza historyczność pierwszych trzech rozdziałów Księgi Rodzaju, a konkretnie prawdziwość przedstawionych tam osób i wydarzeń. Wyklucza możliwość interpretacji tego fragmentu wyłącznie jako alegorii ${ }^{59}$.

Bezpośrednio do tych samych problemów odnosi się encyklika Humani generis Piusa XII z 1950 r. Dokument ten zdaje się prezentować następujący układ między rzeczywistością przygodną i wieczną: rodzaj ludzki znajduje się w centrum świata, który nie jest prezentowany głównie jako zestaw bytów ożywionych i nieożywionych, stający naprzeciw człowiekowi. Konfrontuje się on teraz głównie z rozmaitymi ideami oraz prądami filozoficznymi, a także własnymi negatywnymi skłonnościami będącymi spuścizną grzechu pierworodnego. Ponad tym znajduje się Bóg, którego opatrzność czuwa i rządzi uniwersum. Kierunek $w$ górę $\mathrm{w}$ odniesieniu do wszystkiego, co Boskie jest charakterystyczny dla tego dokumentu. Określa on też relację Stwórcy do ludzi - jest On stroną przede wszystkim nad-rzędną. Humani generis podtrzymuje tezy Vaticanum I, że rozum ludzki jest w stanie osiągnąc pewne i prawdziwe poznanie osobowego Boga, a także prawa przyrodzonego, które Stwórca wyraził w sercu człowieka ${ }^{60}$. Dodaje jednak, jakby uzupełniając Dei Filius, że na drodze ku temu stają popędy z grzechu pierworodnego, a także wyobraźnia oraz zmysły. Mogą one stanowić przeszkodę, ponieważ prawdy o Bogu i stosunku, w jakim znajduje się On do Swoich stworzeń wznosza się ponad zmystowość i wymagają zaparcia się siebie.

Pius XII polemizuje między innymi z fatszywym historycyzmem a także filozofią egzystencjalizmu - mają one pewien związek z kreatologią, natomiast najbardziej tyczy się jej zagadnienie ewolucji, z jakim Kościół zetknął się jeszcze w XIX wieku. Humani generis jest wglądem w sytuację jaka zapanowała w związku z tą teorią. Nie rozstrzyga arbitralnie o jej prawdziwości, popiera dyskusje naukowe

\footnotetext{
58 J. Ratzinger, Tradition, w: op. cit., 201.

59 Breviarium Fidei, Dekret Komisji Biblijnej, por. BF, V, 26-27.

${ }^{60}$ Pius XII, Humani generis, 12 VIII 1950.
} 
theology of creation that the Church provides in this document, but the most important content.

The Church's entry into the 20th century is marked by the development of exegesis and interpretation of Scripture. In this respect, particular work can be seen in the first chapters of Genesis. In the perspective of this work it can be described as a return of dogma to its sources, a natural direction of its reading and interpretation. ${ }^{57}$ A decree of the Biblical Commission, created by Leo XIII, states the historicity of the first three chapters of Genesis, namely the truthfulness of the people and events presented there. It excludes the possibility of interpreting this passage solely as an allegory ${ }^{58}$.

The same problems are directly addressed by the 1950 encyclical Humani generis of Pius XII. The document seems to present the following arrangement between a casual and an eternal reality: mankind is at the centre of the world, which is not presented mainly as a set of animated and inanimate beings, facing mankind. It is confronted mainly with a variety of ideas and philosophical currents, as well as its own negative tendencies that are the legacy of original sin. Over this there is God, whose providence guards and governs the universe. Upward direction with regard to everything divine is characteristic of this document. It also defines the relationship between the Creator and people - he is the superior party above all. Humani generis supports the theses of Vaticanum I whereby human reason is able to achieve a certain and true knowledge of the personal God and of the natural law which the Creator expressed in the human heart ${ }^{59}$. However, as if to complement Dei Filius, it adds further that drives from original sin, as well as imagination and senses, hinder it. They can be an obstacle because the truths about God and the attitude

57 Ratzinger, J. Tradition, in: op. cit., 201.

58 Breviarium Fidei, DECLARATION IN DEFENSE OF THE CATHOLIC DOCTRINE ON THE CHURCH AGAINST CERTAIN ERRORS OF THE PRESENT DAY, see BF, V, 26-27.

59 Pius XII, Humani generis, 12 VIII 1950. 
na ten temat, sprzeciwia się jednak stosowaniu ewolucji jako klucza interpretacji całej rzeczywistości. Zamyka także drogę dyskusji teologicznej w kwestii poligenizmu. Krystalizuje się więc konkretne i pewne twierdzenie -ludzkość pochodzi od Adama, jako jednostkowego człowieka. Encyklika ta jest więc świadectwem bliskiego zetknięcia się nauk filozoficznych, biologicznych i teologicznych. Kładzie ponadto nacisk na poszczególne punkty filozofii klasycznej oraz antropologii, szczególnie na realne możliwości poznawcze rozumu ludzkiego. Przyświeca mu prawda objawiona, porównana do gwiazdy (znów kierunek w górę). Rozum ludzki jest zdolny uzyskać prawdziwe poznanie rzeczy stworzonych (na czym opiera się system teologii katolickiej), udowadnia istnienie Boga osobowego, osiąga niejakie rozumienie tajemnic z nieba ${ }^{61}$. Przeszkodę dla niego stanowią skutki grzechu pierworodnego (który to temat również porusza Pius XII, pisząc o dekonstruowaniu tej idei, skutkującym zniekształceniem centralnych tajemnic wiary).

Zwieńczeniem mojej kreatologicznej analizy jest konstytucja soborowa Gaudium et spes, która dogmat o stworzeniu sytuuje z właściwym dla Vaticanum II rozmachem kontekstowym. Świat ukazany jest znów jako miejsce zmagań człowieka, tym razem gospodarczych, politycznych, kulturalnych i militarnych. Może właśnie z tego względu sobór jakby ściślej dookreśla genezę stworzenia - poprzednio wymieniane były: nicość, wszechmoc, dobroć - tutaj jest to wprost: miłośćc ${ }^{2}$. Początek Księgi Rodzaju zostaje ponownie odczytany i tym, co wynika tym razem z tej deuterozy jest społeczna nauka Kościoła. Stworzony na obraz Boży człowiek jest kobietą i mężczyzną, którzy przeznaczeni są dla wspólnoty ze sobą. Ona zaś stanowi początek i podstawę tzw. społeczeństwa. Żyjący w nim człowiek obecnie siłą rzeczy konfrontowany jest z ogromnym postępem technologicznym, gospodarczym itd., nowymi ideami, które ludzkość prężnie stara się zrealizować oraz problemami, które od wieków stara się rozwiązać.

${ }^{61}$ Ibidem.

${ }^{62}$ II Sobór Watykański, Gaudium et spes. 
He shows towards His creatures completely surpass the sensible order and demand self-surrender and self-abnegation.

Pius XII disputes, among other things, with false historicism and the philosophy of existentialism, which have a certain connection with creatology, but most of all with the question of evolution, which the Church came across as late as the 19th century. Humani generis is an insight into the situation that prevailed in relation to this theory. It does not arbitrarily decide on its truthfulness, it supports scientific discussions on the subject, but opposes the use of evolution as the key to interpreting the whole of reality. It also closes the way for the theological discussion on polygamy. The specific and certain claim that humanity comes from Adam as an individual is thus crystallised. The Encyclical is therefore a testimony to a close encounter between the philosophical, biological and theological sciences. It also emphasises the individual points of classical philosophy and anthropology, especially the real cognitive possibilities of human reason. It is guided by the revealed truth, compared to a star (upward direction again). Human reason is able to obtain true knowledge of created things (on which the system of Catholic theology is based), it proves the existence of a personal God, it brings about some understanding of the mysteries from heaven 60. It is hindered by the effects of original sin (which Pius XII also addresses when writing about the deconstruction of this idea, resulting in the distortion of the central mysteries of faith).

The culmination of this creative analysis is the Council Constitution Gaudium et spes, which situates the dogma of creation with the appropriate contextual momentum for Vatican II. The world is once again presented as a place of human struggle, this time economic, political, cultural and military ones. That may be the reason why the Council, as if to be more precise, is defining the genesis of creation; previously it mentioned nothingness, omnipotence, goodness, but here it is simply: love.$^{61}$ The beginning of Genesis is re-read and this

60 Ibidem.

61 Second Vatican Council, Gaudium et spes. 
$\mathrm{Na}$ tle przedstawionego progresu teologii stworzenia konkretnie widać, na czym polega proces deuterozy. Kolejne relektury w zmiennych warunkach historycznych następujących po sobie epok istniejącej od początku prawdy sprawiają jej rozwój, nie tylko jej, ale też pośrednio związanych z nią dziedzin teologicznych. Wiele myśli nowych stało się nienowymi, pozwalając na dostrzeżenie w przyszłości kolejnych, ukrytych pod powierzchnią sensu. Powracając więc tutaj do myśli P. Beauchampa o deuterozie, że rozumieć, znaczy dotrzeć do podmiotu na grani tego, co wyraża, nie po to, by powtórzyć dosłownie to, co oznajmia, lecz by zwrócić sie wraz z nim ku temu, co daje postawę jego wypowiedzi należy przedstawić objawiający się w tym dogmacie telos. Ujawnia się on, coraz to wyraźniej, w ponawianych odczytaniach orzeczeń doktrynalnych jako Bóg, którego szczególnym przymiotem jest transcendencja, rozumiana zwłaszcza jako istnienie poza poznawalnym światem i przed nim. Jest to pierwsza warstwa telosu, drugą jest rozumienie i wiara w tego Boga, jako Trójcę Osób. Trzecią jest Boska immanencja w świecie, posiadająca swe rozmaite wyrażenia jako vestigia Dei, wcielenie Syna Bożego oraz mnogość innych, które bada teologia. Ten trójaspektowy telos jest właściwym objawieniem, które przynosi kreatologia, rozwija on ją i siebie w jej ramach, a w konsekwencji także pozostałe nauki, wzajemnie z siebie czerpiące. Idea interpretacyjna G. Strzelczyka ukazuje, choćby tylko w pewnym stopniu główne ognisko dynamiki teologii, odsłaniając odrobinę bardziej jej wewnętrzną strukturę z nowej perspektywy. Sam ten fakt, wg tej hermeneutyki uznać można za kolejną udaną relekturę i rozpocząć pod tym kątem studium, tym razem już metateologiczne.

Dogmat to słowo odpierane dziś zgoła pejoratywnie, zapewne z powodu wszechobecnego dziś ducha demokratycznego, który wywołuje niechęć do wszelkich stwierdzeń autorytarnych ${ }^{63}$. Niechęć ta wynika zapewne z braku refleksji nad faktem, że wolność jednostki nie oznacza, iż właściwym dla niej jest to, że swoje poglądy uznaje za absolutne. Jest to pokłosie tak cenionych i zapewne też przecenianych

${ }^{63}$ Międzynarodowa Komisja Teologiczna, op. cit., 301. 
time what emerges from this deuterosis is the social teaching of the Church. Created in God's image, man is both male and female, who are destined to be together. This unity is the beginning and the basis of so-called society. The man who lives there today is inevitably confronted with enormous technological and economic progress, etc., new ideas which humanity vigorously seeks to implement, and problems which mankind has been trying to solve for centuries.

Against the background of the theology of creation presented herein, we can clearly understand the process of deuterosis. Successive reflections in the changing historical conditions of successive epochs of the truth that has existed since the beginning of time contribute to its development, as well as its indirectly related theological fields. Many new thoughts have become non-new, thus revealing more sense hidden under the surface in the future. Moving back here to Beauchamp's thought on deuterosis, where to understand means to reach out to the subject on the ridge of what s/he expresses, not to repeat literally what he or she declares, but to turn with him or her to what gives him or her the attitude of what he or she expresses, telos that manifests itself in this dogma should be presented. It is becoming increasingly evident in repeated readings of doctrinal rulings as God, whose special attribute is transcendence, understood particularly as existence outside and ahead of the cognitive world. This is the first layer of telos, the second is understanding and faith in this God as the Trinity of Persons. The third is the Divine immanence in the world, with its various expressions as vestigia Dei, the incarnation of the Son of God and the multitude of others that theology studies. This three-faceted telos is the right revelation that creatology brings; it develops it and itself within it and, consequently, other sciences that derive from each other. The interpretative idea of Strzelczyk shows, even if only to some extent, the main focal point of the dynamics of theology, revealing its internal structure a little more from a new perspective. According to this hermeneutics, this very fact can be regarded as another successful revision and a study can begin in this respect, this time in metatheological terms. 
dzisiaj cech osobowości jak kreatywność i indywidualność. Czy obecność dogmatów jest dla nich ograniczająca? W pewnym sensie może tak być. Jednak dogmaty same są formułami, których rozumienie przechodzi rozwój i pogłębia się, m.in. dzięki kreatywności oraz indywidualnym zainteresowaniom i czasem niestandardowym podejściem teologów. Dlatego dogmaty są rzeczywistością przede wszystkim wymagającą subtelnego traktowania, jednocześnie prostoty i wnikliwości, pokory i odwagi stawiania śmiałych pytań. Dlatego, kończąc te rozważania, pragnę podpisać się pod słowami św. Augustyna: $J a$ zaś chętnie będę zapytywać innych, nie mając pewności. I nie wstyd mi przyjąc pouczenia, gdybym się pomylit ${ }^{64}$.

\section{Streszczenie}

Niniejszy tekst porusza problematykę interpretacji dogmatu- jako takiego oraz rzeczywistości jego treści. Przedstawia idee biorące udział w tym procesie i wybrane metody interpretacji, ujmujące dogmat z różnych perspektyw, dla ukazania wieloaspektowości zagadnienia oraz wzajemnego uzupełniania się ich. Wyróżnioną ideą jest propozycja G. Strzelczyka, który przekłada hermeneutykę P. Beauchampa dotyczącą interpretacji Starego Testamentu na problem interpretacji dogmatu. Opiera się ona na trzech głównych punktach: arche, deuterozie i telosie. Ukazuje aspekt transcendentny w tym procesie. Inną przywołaną metodą, jest spojrzenie z perspektywy immanentnej, którą proponuje K. Góźdź. Elementem praktycznym jest analiza dogmatu o stworzeniu, dokonana wg metody G. Strzelczyka, która kończy niniejszy artykuł.

Słowa kluczowe: dogmat, interpretacja, idea, arche, deuteroza, telos, rozwój

\section{Nota o Autorze}

Anna Wróblewska: ur. w 1999 r., studentka teologii ogólnej na Wydziale Teologicznym Uniwersytetu Kardynała Stefana Wyszyńskiego w Warszawie.

${ }^{64}$ Augustyn z Hippony, O Trójcy Świętej, tłum. Maria Stokowska, Kraków 1996, 27. 
The dogma is a word that is being rejected pejoratively today, probably because of the ubiquitous democratic spirit that is nowadays arousing aversion to all authoritarian statements. ${ }^{62}$ This reluctance probably stems from a lack of reflection on the fact that the freedom of the individual does not mean that $\mathrm{s} / \mathrm{he}$ considers his or her views to be absolute. This is the aftermath of the personality traits so valued and probably overrated today, such as creativity and individuality. Is the presence of dogma restricting them? In a sense, it may be so. However, dogmas themselves are formulas whose understanding is developing and deepening thanks to creativity, individual interests and sometimes non-standard approaches of theologians, among other things. Therefore, dogma is a reality that requires, above all, subtle treatment, as well as simplicity and insight, humility and the courage to pose bold questions. Therefore, to conclude these reflections, the author endorses the words of St Augustine : If herein I am foolish, let him who knows better correct me; to me at least the case seems as I have said. ${ }^{63}$

\section{Summary}

This paper addresses the issue of interpretation of dogma as such and the reality of its content. It presents the ideas involved in this process and selected methods of interpretation, embracing dogma from different perspectives, to show the multifacetedness of the issue and their mutual complementarity. One of the distinguished concepts is the proposal of Strzelczyk, who translates Beauchamp's hermeneutics concerning the interpretation of the Old Testament into the problem of dogma interpretation. It is based on three main points: arche, deuterosis and telos. It shows the transcendent aspect in this process. The other method mentioned is the immanent perspective proposed by Góźdź. A practical element is the analysis of the dogma of creation, carried out according to the Strzelczyk's method, which concludes this article.

\footnotetext{
${ }^{62}$ International Theological Commission, op. cit., 301.

${ }^{63}$ Augustine, Aurelius. The Trinity. Translated by Maria Stokowska, Kraków 1996, 27.
} 


\section{Bibliografia}

Augustyn z Hippony, O Trójcy Świętej, Kraków 1996.

Góźdź K., Interpretacja dogmatu w: „Studia Theologica Varsaviensia” 2018/1, Warszawa 2018, 13- 28.

I Sobór Konstantynopolitański, Wyznanie wiary 150 Ojców.

I Sobór Nicejski, Wyznanie wiary 318 Ojców.

I Sobór Watykański, Dei Filius.

Kowalczyk M., Traktat o stworzeniu,

Królikowski J., Od wiary do teologii. Dokumenty Międzynarodowej Komisji Teologicznej 1969-1996, Kraków 2000.

Kupiec K., Teologia - wiedza zbawienia. Wprowadzenie do teologii i rozwoju dogmatów, Tarnów 1998.

Müller G. L., Dogmatyka katolicka, Kraków 2015.

Pius XII, Encyklika Humani Generis 12 VIII 1950.

Ratzinger J., Tradition, w: Ratzinger J., Opera Omnia, t. IX/1: Wiara w Piśmie i Tradycji. Nauka o zasadach teologicznych, Lublin 2018.

Ratzinger J., Wprowadzenie w chrześcijaństwo, Kraków 2007.

Sesboüé B., Bóg zbawienia. Tradycja, reguła i Symbole wiary. Ekonomia zbawienia. Rozwój dogmatów trynitarnych i chrystologicznych. Wydawnictwo „m” 1999.

Strzelczyk G., Dogmat jako granica: hermeneutyka Paula Beauchampa a interpretacja dogmatu(-ów) w: „Kościół wobec granic”, Katowice 2005, 43-56.

Valverde C., Antropologia filozoficzna, Poznań 1998.

Wagner H., Dogmatyka, Kraków 2007. 


\section{Summary}

The present text touches issues of dogma interpretation - in se ipsum and the reality of its content. It presents ideas that take part in this process and chosen methods of interpretation, showing dogma from different perspectives in order to present many sides of this issue and its complementarity. A distinguished idea is G. Strzelczyk proposition. He uses hermeneutics of P. Beauchamp that concerns interpretation of the Old Testament to explain the problem of dogma interpretation. His method is based on three main points: arche, deuterosis and telos. It shows transcendence aspect in this process. Another recalled method is a perspective of immanence, suggested by K. Góźdź. Practical element is the analysis of dogma creation, made according to the first (G. Strzelczyk's) method which ends the following article.

Keywords: dogma, interpretation, idea, arche, deuterosis, telos, progress

\section{About the Author}

Anna Wróblewska born in 1999, student of general theology at the Faculty of Theology of the Cardinal Stefan Wyszyński University in Warsaw.

\section{Bibliography}

Augustine, Aurelius. The Trinity. Translated by Maria Stokowska, Kraków 1996. Góźdź K., Interpretacja dogmatu in: „Studia Theologica Varsaviensia” 2018/1, Warsaw 2018, 13- 28.

First Council of Constantinople, Exposition of Faith of the 150 Fathers.

First Council of Nicaea, Profession of Faith of the 318 Fathers.

The First Vatican Council, Dei Filius.

Kowalczyk M., Traktat o stworzeniu,

Królikowski J., Od wiary do teologii. Dokumenty Międzynarodowej Komisji Teologicznej 1969-1996, Kraków 2000.

Kupiec K., Teologia - wiedza zbawienia. Wprowadzenie do teologii i rozwoju dogmatów, Tarnów 1998.

Müller, G.L. Catholic Dogmatics for the Study and Practice of Theology, Herder \& Herder; Reprint edition (October 1, 2017).

Pius XII, Humani Generis 12 VIII 1950. 
Ratzinger, J . Tradition, in: Ratzinger, J . Opera Omnia, vol. IX/1: Wiara w Piśmie i Tradycji. Nauka o zasadach teologicznych, Lublin 2018.

Ratzinger J., Introduction to Christianity, Kraków 2007.

Sesboüé B., Sesboüé, B. (1999) God of Salvation. Tradition, Principle and Symbols of Faith. The Economics of Salvation. Development of Trinitarian and Christological Dogmas. Wydawnictwo „m” 1999.

Strzelczyk G., Dogmat jako granica: hermeneutyka Paula Beauchampa a interpretacja dogmatu(-ów) in: „Kościół wobec granic”, Katowice 2005, 43-56.

Valverde C., Philosophical Anthropology, Polish edition: Poznań 1998.

Wagner H., Dogmatics, Kraków 2007. 